\title{
Islam in the Post-Communist Balkans: Alternative Pathways to God
}

\author{
Arolda Elbasani \\ Robert Schuman Centre for Advanced Studies (RSCAS), Florence \\ Olivier Roy \\ Robert Schuman Centre for Advanced Studies (RSCAS), Florence
}

\begin{abstract}
The Islamic 'revival' in the Balkans has raised many questions among mainstream politicians and academics, who tend to look at religion as a repository of ethno-national identities, and hence a risky 'depot', furthering divisions between and among national entities. How believers themselves discover, articulate and experience their faith, is often lost in the grand narratives of nations' assumed uniformity and the related criteria of inclusion and exclusion. This article shifts the analytical and empirical focus from nation-centric debates on the revival of Islam to believers' self-discovery and pursuit of faith after the fall of Communism. Specifically, it explores the emerging actors and mechanisms that trigger the bifurcation between Islam as a marker of national identity on the one hand, and a source of religious beliefs on the other. It all depends on who speaks for Islam-state authorities, religious hierarchies and/or informal faith communities. All the while, the Islamic phenomenon is no longer merely the bearer of ethnonational alternatives, but also the symptom of new spaces containing a variety of new actors as well as overlapping national, regional and global processes.
\end{abstract}

Keywords: Islam; religion and politics; nation-building; ethno-religious identity; Balkans 


\section{Introduction}

The post-Communist resurgence of Islam across the Balkans has raised many questions, which are still exclusively studied within the context of the rise of nationalism and the violent conflicts of the early 1990s. The dissolution of the former Yugoslavia and the ferocity of conflicts and violence, moreover, have confined research to the most striking cases and particular moments in time (Poulton and Taji-Farouki 1997, 1). Consequently, the exploration of the Islamic phenomenon is left to the mercy of nationalist and post-conflict paradigms, which necessarily essentialize the revival of Islam according to the ethno-religious divisions of the day (Henig and Bielenin-Lenczowska 2013). However, the liberalization of religious conduct, and the normalization of the political arena in the two decades since the fall of Communism has unleashed a myriad of new encounters between believers and nationally envisaged religious categories and roles. In the 'opened up' religious market, believers face different sources of knowledge and interpretation, and are more apt to choose, but also resist and recast the collective national divisions within which they maneuver.

This article explores the actors and mechanisms that shape the emerging gap between collective categories of state-organized religion and believers' self-discovery and experience of religiosity in the post-Communist era. Who frames the national religious 'field' and the categories upon which it builds? How do believers navigate these categories and choose how to pursue them and indeed what it is to be a good Muslim in the open market of religiosities? How do they recast the relationship between nation, state, and faith? And what are the resulting pathways to God? 
We approach these questions by critically analyzing the features of the state-organized religious fields, and shifting the empirical focus to the disruptions of related categories in the liberalized post-Communist religious spaces. To this end, we differentiate between two crucial concepts: Religion here defined as a coherent corpus of beliefs managed by a body of legitimate holders of knowledge; and religiosity defined as individual believers' own formulations and experiences of faith (Roy 2007, 7-8). Focusing on believers as agents with the capacity to reformulate and recast religious categories permits us to analyze the resurgence of faith at the intersection of the political and the sacred, the national and the global, the past and the present.

The analysis proceeds in four sections. Section One unpacks mainstream research, which considers religion, and particularly Islam, as a marker of ethno-national communal identities. Section Two outlines the actors and mechanisms that sustain the state-organized religious field and its ideological pillars. Section Three investigates the contemporary 'breaks' that challenge the official religious sphere and provide believers with new alternatives and ideas to pursue their faith. The following empirical analysis brings together cross-country evidence on the diffraction of Islam into different actors with alternative approaches concerning the resurgence of faith: State authorities and official Islamic hierarchies that frame religion in the name of the nation on the one hand, and autonomous faith communities that assemble around informal structures and alternative sources of knowledge and interpretation on the other.

The findings presented herein suggest that Islam, as framed at the macro-political level, remains an important marker of identities, but the experience of religiosity has increasingly become more 
individual in nature, but also detached from organized religion and official doctrinal prescriptions. Believers' recasting of Islam after the fall of Communism is increasingly personal, mobile, weakly institutionalized, and collective as a choice. The 'de-nationalization' and 'deethnization' of Islam does not necessarily entail a 'de-culturation,' but rather a re-formating of the connection between religious, cultural and political markers. The result is the revival of Islam as faith, not as a collective identity or organized form of 'belonging'. At a more general level, our analysis sheds light upon timely and pertinent theoretical questions concerning the actors that speak for Islam, the role of foreign influences, and the recasting of the relationship between nation, state and faith, as well as patterns and traits of Islam in the broader post-Communist context.

\section{Islam as a National/Ethnic Marker}

Mainstream research on Islam in the Balkans, similarly to that concerning other denominations, is permeated by an implicit and sometimes explicit assumption that religion serves to shape and demarcate clear national/ethnic boundaries. Religion in general is reduced to an ethnic marker, a crucial and yet divisive source of national identity. As Creed notes, the scholarly privileging of ethno-national identities, at the expense of local identities and localized forms of knowledge and practice, represents an 'example of Balkanism par excellence' $(2011,168)$. This insistence upon the role of religion in confining communal identities is particularly related to the march of national ideologies and the vicissitudes of state- and nation-building processes amidst imbroglio 
and conflict between diverse ethno-religious groups that happened to share the same political space.

The enmeshment, and often subjugation, of these divisions to the politics of national identity, became especially pronounced during the violent collapse of Yugoslavia. The new entities that resulted from the dissolution of the federal state structure all claimed to represent a dominant ethnic collectivity identified with a specific religion, by effectively managing a transformation process that Verdery calls the 'extermination of alternative identity choices' (1994, 38). However, it was the bloodshed in Bosnia-Herzegovina that brought worldwide attention to Muslim communities, their ethnic allegiances and the course of nation- and state-formation in these parts of Europe. As Poulton and Taji-Farouki note, 'the Bosnian tragedy has made very clear the importance of examining the relationship between the Balkan Muslim communities and the states in which they live' $(1997,1)$. Then came Kosovo, another case of political conflict that developed along ethno-religious lines, namely between Muslim Albanians and Orthodox Serbs. Subsequently, conflicts in Macedonia drew new attention to hard-core divisions between Orthodox Macedonians and Muslim Albanians, both barricading themselves into opposing 'ethno-religious' fronts. The battles for state authority, power, territory, and independent statehood in the 1990s, all capitalized on religious divisions as crucial instruments for the reconstruction of the national 'self' and the opposing 'other' (Duijzings 2000, 157). All the while, churches and mosques became major targets of destruction and embodied the emerging conflicts. 
For many, the events of early 1990s only recalled a historical course of ethno-religious imbroglio among and between the new polities that carved their independent statehood out of former Ottoman territories in the Balkans. The legacies of the Ottoman rule, particularly the millet system of organization, whereby religion was used to define separate communities, nurtured a strong sense of in-group belonging, determined almost exclusively by confession (Poulton and Taji-Farouki 1997). The weakening of the Empire in the $19^{\text {th }}$ century paved the way for competing European concepts of modern state organization and authority. However, even where confessional divisions were eroded by competing sources of identification, institutional legacies, group allegiances and daily practices at the local level helped to preserve a sense of distinct religious communities, which continued to separate and undermine the aspiring new nations.

In the age of nation- and state-building, these distinguishable communal identities were promoted, manipulated and usurped by political schemers of all sorts in order to demarcate their new nations, engineer homogeneity, consolidate central state authority, reconfigure borders, and, when necessary, wage wars against 'others'. Modern state-making presses its subjects towards single identities: one cannot keep track of people who choose to be one thing at one point and something else at another. In the Balkans, similar to the 'construction' of ethno-national identities in Western Europe, "the self-consistent person who "has" one "identity" is the product of a specific historical process: modern nation-state formation' (Verdery 1994, 37). In this process, religion was taken out of the hands of the believers and subjected to various state ideologies and political projects - secularism, patriotism, ethnic mobilization, national unity and centralized state authority - which had very little to do with faith itself. Intellectuals and sometimes even the Muslim clergy actively participated in this process. Yet, more often than not, 
it was the political authorities that projected and led large-scale reforms to engineer a homogenous national 'we-ness'. Indeed, attempts by political entrepreneurs, but also by centers of religious power, to agitate for the eradication of elements of blend and mixture were livelier in border and composite areas, where ethnic and national loyalties remained the most fluid (Duijzings 2000).

Islam, which enjoyed particular political and legal advantages during the centuries of Pax Ottomana, became the very backbone of new political engineering during the processes of 'reimaging' national regimes that spun out of the dissolution of the Empire. The predominantly Christian-Orthodox Balkan states that gained independence in the period from 1829 to 1878 Serbia, Greece, Romania, Montenegro and Bulgaria - all identified themselves with the national Orthodox churches in order to consolidate their newly-won statehood (Poulton and Taji-Farouki 1997, 25). Only Albania, which inherited a mixed religious population and could not clothe nationalism with a single creed, attempted to forge an 'ecumenical' nation-state (Clayer 2008). Regardless of their composition, all of the post-Ottoman Balkan states targeted their Muslim communities as a leftover of the Ottoman past, almost a traitor in the midst of their nations in the making (Katsikas 2009, 539). Their nation- and state-building strategies included various antiMuslim policies: foreigners to be expelled; stigmatization vis-à-vis the dominant ethno-religious group; measures of homogenization; and, at best toleration as a separate ethno-religious group. Muslim communities, for their part, had to carve a new place for themselves amidst largely nonMuslim societies, exclusive nation-building projects, antagonistic policies, and the shifting fortunes of the European geopolitical order. 


\section{The State-Organized Religious 'Field': Legacies, Categories and Transmission Mechanisms}

The re-awakened nationalisms of the 1990s, which were certainly suffused with old ethnoreligious symbolism, informed the dominant readings of Islam also after the fall of Communism. As a recent study puts it, 'the interpretation of ... Muslim politics as trapped in the politics of identity and inter-communal ethno-religious nationalism prevails in the media, political debates and international community's projects as well as in academic discourses' (Henig and BieleninLenczowska 2013, 2). Violence contributed in solidifying national projects: 'it makes reality resemble the ideological constructs that underpin the violence' (Duijzings 2000, 33). Hence, during and for some time after the Balkan conflicts, analysis of the various Islamic phenomena was left at the tender mercy of nationalism and post-conflict studies, which continued to reinterpret religion in line with ethnic splits and static national categories.

The inbuilt divisions carried the active contribution of post-Communist political elites to 'nationalize' but also 'centralize' and 'manage' newborn Islamic impulses within the frame of the central state authority. Such policies of nationalization-cum-etatization of Islam often served worldly interests of subjecting religion to the service of concrete political projects and agendas (Hann and Pelkmans 2009, 1520). All modern states maintain boundaries by mastering clear criteria for inclusion and exclusion, but this was especially pertinent in light of the centralized legacy of the post-Communist state apparatus. Former Communist regimes had built up a highly centralized machinery to appropriate and control all spheres of life, including public religions and intimate spheres of personal piety. Succeeding post-Communist entities capitalized on the 
power of the state machinery to construct, select and also use religious symbols as an anchor of political legitimacy. Institutionally, the state continued to closely monitor nations' religious life by preserving a multi-tiered system of registration, screening and controls. Although the management of Islam depended upon their demographic and historical weight, the use of states' muscles to discipline it remained the same. Communist-style centralization and modernization thus bequeathed vestiges of largely interventionist and occasionally hostile state policies to the post-Communist institutional models of managing Islam.

At the same time, some of the Communist ideological templates spilled over into postCommunist arrangements to 'check Islam at the door' of the succeeding nation-states. Former state intelligentsias - historians, linguists, ethnographers, writers, artists and students of Marxist ideology - supported by an overstaffed academy and generously funded by the Communist regime, worked as active transmitters of Communist ideas into the new religious sphere. The previous regimes educated and made use of state intelligentsias in order to articulate their nation's politically appropriate heritage, complete with a pantheon of great thinkers, artists, writers and heroes. After the regime change in the 1990s, these intellectuals took up key positions in the new machinery of the reproduction of knowledge, generating what Gellner has dubbed the 'diffusion of a school-mediated, academy supervised [national] idiom' $(1983,140)$. Indeed some of the Communist-educated intellectuals turned towards Islam as a political option, but the anti-Islamic penchant of broad intellectual discourse remained a strong feature of postCommunist societies. In the new spectrum of post-Communist nationalisms, Muslims were commonly seen as some kind of ethnic 'fifth column', remnants of a bygone era, which could never be successfully integrated into the planned modern, European, and often exclusively 
Orthodox nation-states. Hence, public expressions of Islam had to be oppressed, kept out of the public realm or placed under state surveillance. Such accounts of nations' 'heritage' and related versions of history enforced stagnant parameters on how the nation, state and Islam merged or parted ways in the official memory of each political entity.

Government-sponsored 'official' Islam - an organizational concept, which refers to the creation of centralized religious hierarchies approved by the state - serves as yet another powerful interlocutor of transmitting politically-conceived national accounts of Islam (Oktem 2011, 162-3; Elbasani 2015). Headed by a Chief Mufti, governed by formal statutes, and supported and monitored by the state, central hierarchies are formally acknowledged as the sole authority that can issue binding decisions in all administrative and spiritual issues pertinent to the Muslim community. The Muslim networks and activities revived after the fall of Communism rarely fit smoothly into this model of central management of religious affairs. Still, the religious hierarchies enjoy a formal privileged status - they have the monopoly of the management of religious endowments, the maintenance of religious infrastructure, the organization of religious education, and the representation of Muslim believers in relevant public activities. Additionally, they have preferential relations with the state - they are the only associations that can negotiate bilateral agreements with the state, engage in dialogue with state authorities, be represented in the state institutions, enjoy free access to state media, and benefit state funds, roles which distinguish them as the only 'authority' in charge of governing the community of Muslim believers (Elbasani 2015). Even where pragmatic interests or ideological rifts have divided official Islamic structures, the state authorities have made sure to remedy these problems and affirm its selected interlocutors. The official hierarchy, in return, has helped to establish state 
oversight over the community of believers and to cleanse alternative foreign influences (Ghodsee 2010, 19). By offering specific benefits and co-opting the Islamic 'establishment', the postCommunist states continued to maintain an intricate relationship with the official Islamic structures - the sovereign has the prerogative of control and intervention, Ulamas are domesticated, religious ideas tamed, and scholarship corrected.

It is through this coalition of 'the powerful', operating under the backing of the state, that political constructs of religion, nation and history were reinforced and perpetrated in different countries. These coalitions necessarily reproduce inflexible 'boundary-drawing' categories on and within Islam itself. All the while, believers' recovery of piety and observance, as well as referents of faith, is commonly filtered through the ethno-national categories that the stateorganized religious 'fields' animate and nourish.

\section{New Encounters of Faith: Believers, Choices and Diversity}

This top-down assignment of ethno-religious collective identities and uniform terms of belonging that characterize state-organized religion represents one account of the postCommunist trajectory of Islam. Another account denotes believers' own searches and pursuits of various 'identities' on offer during the opening up of the religious space. The two levels are interrelated. Believers respond to the broad socio-political contingencies, which affect their personal and communal lives. Enrolment within communal categories becomes particularly 
strong during radical moments of war, violence and conflict, which force believers to choose where they belong and/or to stick together.

Still, the faithful are active agents with the capacity to choose and reinvent the national classificatory systems within which they manoeuvre. Rituals and living practices often function as a means of de-authorising hegemonic ethno-religious perspectives that privilege collective identities (Creed 2011). Believers, moreover, encounter different sources of identification, and actively select and weigh the value of each according to their surrounding circumstances and personal experiences. Mixed identity choices are frequent, particularly in peripheral settings where ecclesiastical organizations and state institutions are less powerful in reaching and determining believers' preferences. The more one moves out of and away from centrally organized religious machinery, the more one observes Muslim 'anomalies' - ethno-religious fusion, heterodox practices, cultural diffusion and plural forms of belonging and believing (Henig and Bielenin-Lenczowska 2013). As Duijzings notes: 'there is always friction between the ideal ethno-religious models or ideologies produced by states and religious regimes, and the social reality to which they refer' $(2000,25)$. Seen from the autonomous spaces of believers' discovery and practice of faith, 'being Muslim' takes multiple forms across different countries, localities and moments of transition.

The post-Communist open market of religiosity has moreover expanded the scope of 'identity' choices available to Muslim believers. At least three crucial developments here - namely 1) the phenomena of Socialist-style secularization; 2) the intrusion of international influences; and 3) the 'EU-ization' of the religious sphere - contribute to challenging and reconfiguring the one- 
size-fits-all ethno-national formulas into which Muslims are commonly squeezed. These breaks in the organized religious field confront believers with different, sometimes contradictory and sometimes competing sources of influence, both internal and foreign, regional and global, formal and informal, secular and sacred.

\section{The Imprint of Secularization}

The Communist-style modernization, and the eviction of religion from the public arena, has contributed to a certain 'secularization of Balkan societies' and 'a sharp decline in religious practice' (Bougarel 2005, 11). Region-wide polls show that the majority of citizens declare that they believe in God and belong to one of the religious communities, but only a few attend communal services (University of Oslo 2011). Instead, post-Communist citizens prefer to attend only important ceremonies at poignant moments in life such as births, wedding and funerals. They also appear committed to confining religion to the private sphere - away from institutions, schools, arts and the public sphere more generally (ibid; Oktem 2011). Even when the bitter nationalist struggles solidified Muslims' identification with a core ethno-national group, this did not result in the uniform Islamization of their religious identities, be it in the sense of religious rituals, discovery of a global Umma, and/or unquestioned loyalty to the organized religious establishment.

\section{International Influences}


Another trend, which destabilizes the organized religious field, and surfs the wave of autonomous religious choices, came with the intrusion of various external influences into the porous institutional order that characterized the collapse of Communism. The liberalization of religious conduct and the opening of channels of communication with the world created a vivid and competitive 'marketplace', where foreign actors and ideas - missionaries, migrants, students from abroad, humanitarian organizations and virtual Internet networks - competed with established institutions and national ideologies for market 'shares' (Elbasani 2015; Karcic 2010). Cash-rich Arab organizations and a myriad of other Middle Eastern and Turkish organizations, targeted Muslim communities in the Balkans, not only to win post-atheist souls, but also to gain a foothold in the midst of Europe. They provided the lion's share of financial sources for the recovery of Islam: funds for the re-building of infrastructure, scholarships for students abroad, foreign literature, local translations, religious missionaries, education networks, and abundant humanitarian assistance. At least some of those associations also insisted upon propagating a message of Islam pure of local inventions. Such movements and their ideas managed to infiltrate the local institutions, made inroads amongst the uprooted and the poor, attracted groups suffering the hardship of economic collapse, and preached an appealing message of equality and justice amidst the corrupt post-Communist political order (Ghodsee 2010). Yet, the dilemmas that came with foreign Islamic movements and their interpretations pushed local Muslims to search for ideas most appropriate to their societies and to take ownership of their own local 'ways' of pursuing faith (Karic 2002).

\section{The Europeanization of the Religious Space}


A third factor, which disrupts and reconfigures the organised religious field, is Muslims' access to a broader European institutional and normative space, now closely related to the ongoing processes of EU accession (Elbasani 2013). The promise of EU membership to all countries in the Balkans has brought them into closer contact with the European project and Europe-wide debates on what it is to be a good Muslim in contemporary Europe. EU-level debates, often intermingled with issues of enlargement fatigue, Christian heritage, problems of migration, issues of terrorism, and the uncertainty of Turkey's accession, add to pressure on Muslim believers to position themselves along the indigenous side of 'European Islam'. The term certainly reflects Muslims' historical engagement with institutional and ideological templates emanating from the European continent (Clayer and Germain 2008). Yet, in the post-Communist era, the term 'European Muslim' is now reframed to suggest Muslims' active support for the post-1989 project of 'return' to Europe and the concrete criteria of EU accession - democracy, the rule of law and the market economy -with which candidate countries need to comply. At the same time, Muslims perceive the EU institutions and rights of citizenship as an international layer of protection against restrictive national arrangements and ideologies (Elbasani and Saatcioglu 2014). Muslims have discovered that the EU's democratic requirements expand the range of domestic rights (Ghodsee 2010, 177). Different Muslim groups mobilize the language of EU's norms and values associated with the highest standards of democracy - freedom of speech, opinion, conscience, property, and minority protection - in order to broaden their claims in the domestic arena.

\section{Alternative Discoveries of Islam}


The post-Communist 'disruptions' of the state-organized religious field have unleashed a myriad of new actors with various alternatives and solutions concerning the revival of faith: 1) state authorities; 2) official Islamic institutions; and 3) informal faith communities. It all depends upon who speaks for Islam.

\section{Protective Nationalisms: Extolling Endogenous versus Foreign Islam}

State authorities and official Islamic institutions often ally together in order to protect the official articulation of Islam and consequently portray competing forms of faith as 'foreign' and/or alien to the ideas of national identity, thus antagonizing many 'born-again' Muslims. Ambivalence towards Islam is a recurrent and structurally inbuilt feature of old and new Balkan nationalisms, but it has reappeared in full force during the post-Communist re-organization of the religious sphere. Balkan polities, at least at the macro-political level, continue to see Islam as a disputed 'other' amidst their 'European' states in the making. Accordingly, Islam requires state control and conjectural reformation in order to 'fit' the ethno-religious structure of respective nationstates.

Political and academic entrepreneurs that 'guard' the Balkan nations also define the borders of acceptable 'traditional' Islam(s), typically framed in the context of a nation's cultural and historical particularities. Expressions of faith that do not fit into this traditional 'fabric' are exposed to misnomers ranging from enemies of the nation to remnants of a bygone era, to odious renegades and foreign agents. The dichotomy between 'ours' and 'theirs', local and foreign, 
national and global, and ultimately, good and bad Islam(s) builds on nation-based categories. In this vision, national or traditional Islam is portrayed as 'moderate' - liberal, tolerant, and European - whereas global or foreign Islam is perceived as alien, fundamentalist, and possibly intolerant and radical.

Within the exclusive nationalist accounts, the revival of Islam and changes in religious practices and beliefs are often linked to foreign influences that penetrated the Balkans after the postCommunist liberalization of religious conduct in the 1990s. In Albania, mainstream public intellectuals problematize the revival of Islam by employing orientalist stereotypes that juxtapose Albanians' broad-brush European identity with the 'backward' imported trends of Islam (Sulstarova 2015). Pronounced forms of religious practices are commonly exteriorized. As one of Tošić's informants suggests, 'this is foreign to us. It comes from Saudi Arabia and there is money involved! We are Europeans. We do not need this here!' (2015). The contrast between traditional European strain of Islam and imported extremist currents also sparks intensive debates in Bosnia (Mesarič 2015). Here, Salafism and its expressions are similarly deemed as practices 'incompatible with Bosnian-cum-European culture'. In the same vein of argument, Olson's study of Bulgaria suggests that both the government and the media propagate the Orientalist myth that 'Islamic revival has been imported wholesale from the Middle East, through the efforts of Arab organizations with ties to terrorism' (2015). By 'externalizing' the resurgence of Islam, political and intellectual elites tend to look down upon practicing Muslims as some kind of externally transplanted faith community, which undermines the 'endogenous' tradition. 
Foreign movements, for their part, are also divided into competing trends, mainly: 1) Salafism, either in an institutional form, largely sponsored by Saudi Arabia, or in a de-institutionalized form, driven by informal networks, including individual imams and militant missionaries; and 2) the neo-Ottoman model, sponsored by Turkish official state structures (Diyanet) or non-official institutions such as the Gülen networks. Both trends are further divided among themselves into separate schools and networks propagating different interpretations of Islam. These 'interferences' play out at the macro-political level and manifest themselves in the form of national identity 'threats', but also regional shifts of power and clashes of civilization. For the defenders of traditional Islam, Salafi religious predicators and missionaries, militant NGOs (Gülen schools), or cultural or religious activities sponsored by foreign states (TIKKA for Turkey, or the OIC), are seen as reinforcing the ethno-religious rivalries and reshaping them into a geo-strategic, regional, and broad civilizational confrontation. Accordingly, not only the unity of the nation, but European 'civilization' itself, is at stake. In the words of one of the Metropolitans of the Greek Orthodox Church,

Asian peoples invade Europe threatening to alter the synthesis of its population. After that, the spirit of Islam and its traditions will dominate. Within a multicultural world the winner will be race, the population that will dominate over the other. Now, Muslims fight to dominate biologically and become a majority in Europe. The shrinking of the White World has been prepared. Unfortunately, Europe faces a serious situation. (Quoted in Sakellariou 2015) 
Indeed, mainstream political and intellectual elites across the Balkans have been quite receptive of the thesis on a 'civilizational' divide between East and West, and the contested role of Islam in its midst. Highly acclaimed intellectuals in Albania, for example, ponder the obstacles that Islam poses in their country's path towards Europe and frame the issue as a choice between East and West (Sulstarova 2015). In Kosovo too, political elites seek to distance the fragile state structure from any identification with the Islamic majority by downplaying its institutions and symbols (Mehmeti 2015). Both countries have devised a similar policy of 'detaching' Islam from the definition of an aspired 'European' national identity and especially the political project of 'return' to Europe.

The chains of transmission work top-down - political elites and state bureaucrats establish the institutional confines, intellectual circles supply suitable historical narratives, and official religious hierarchies diffuse the official line across the community of believers. Official Muslim organizations, each based near centres of political power in Sarajevo, Prishtina, Tirana, Skopje, Sofia and so on, maintain the organizational tools - the faculty of Islamic Studies, a network of Madrasas, as well as intellectual, publication and humanitarian activity nets - to distribute the national/traditional visions of Islam. The Islamic Community in Bosnia, for example, ascribes itself the role of protecting and following the tradition of the Bosniaks. A resolution adopted in 2006 obliges the community to protect 'the authenticity of the centuries old tradition,' and imams to take into account the 'Bosnian tradition' when interpreting Islam (Mesarič 2015). The Grand Mufti and his representatives in Bulgaria follow a similar line of traditional Islam that is strongly rooted in the fabric of Bulgarian local culture and European 'belonging' (Olson 2015). Pursuing the 'tradition' is also the foremost goal of the Albanian Central Muslim Organization, 
which describes itself as an 'engine in the promotion of highest Islamic and patriotic values' and pledges to 'develop a feeling of love and faithfulness for the religion and the Fatherland' (Endresen 2015). Concurrently with the project of European orientation, the Muslim hierarchy in Albania describes the country as one of a 'Muslim majority', but with a 'Western spirit', a 'Western vocation' and 'Western ethnic origins' (Ibid.).

\section{Believers' Choices and Informal Faith Communities}

The common juxtapositions between local traditional Islam and imported foreign Islam miss the in-situ evolution of autonomous 'faith communities', informal structures where members of an ethno-national group or sub-group endeavour to build a community of believers within a larger group of 'cultural Muslims'. Believers tend to understand Islam as a religion and not as a culture; they are local pious people who organize meetings, prayers and classes without seeking any form of institutionalisation or authority. They do not necessarily reject the concept of local culture, they do not consider less observant neighbours as 'infidels', they just want to 'purify' and observe religious norms. They thus aim to define a religious attitude towards the world that does not consist of 'belonging' to a cultural group, but rather of freely incorporating and practicing religious norms and values in their daily lives.

The ritual of Friday prayer and the wearing of the hijab in Bosnia for example show that believers frequently avail of their right of personal choices in order to pursuit their faith. As one of Funk's interlocutors admits, 'in Bosnia nothing seems to be farz, an obligation by God... we somehow choose everything. It is an obligation but we do it as our free choice' (Funk 2015). 
Believers' resort to personal choice is particularly visible in the donning of the hijab. The emergence of informal teachers of Islam in Bulgarian villages also shows that at least some of them advocate individual choice: 'Everyone has the right to choose. A girl who dresses like that [in dark colors] is saying, "I want to dress like this!: ... But there are very modern [Muslim girls, women] - they put on a headscarf, they wear pants and for example a tight shirt, which absolutely is not a problem.' (Olson 2015)

The younger generation of covered women in Bosnia is indeed quite innovative in wearing the hijab and showing that veiled women 'can be nicely and fashionably dressed' (Mesarič 2015). When believers are deprived of the right to wear the headscarf, as in Kosovo, they consider it a restriction of individual freedoms and urge their elites to look 'to Europe and the rights enjoyed by Muslims there' (Sadriu 2015). The reverse, however, can also be true in the discourse of Imams that propagate for the 'purification' of Islam. A Saudi-educated Imam in Bulgaria for example instructs his followers that the 'West' makes use of different ways to 'ruin' Muslim women:

Television (especially soap operas and advertisements which showed partially naked women); education (especially sending one's daughter abroad to study); celebration of 'others' holidays' in school (such as Christmas); graduation ceremonies; promotion of 'ruined women' (pop singers) as the 'stars of Bulgaria' (a marketing campaign by one of Bulgaria's most prominent music labels, Payner); and beauty parlors. (Olson 2015)

These informal and diversified faith communities are not insulated bearers of the tradition and national ideologies that their political counterparts propagate. They have access to the Internet 
and to international publications; they might go abroad to study, make pilgrimages, attend conferences, follow online sermons and fatwas, et cetera. They strive for a fusion between religion and rights, faith and identity, knowledge and practice. Their choices evolve at the intersection between national traditions, newly-won freedoms, global influences and access to European institutions and rights. Communication with non-official actors allows Muslims to 'learn' Islam in an open manner, using top-down vertical but also horizontal networks of transmission. The Internet represents a particularly useful tool for them to access alternative sources of information and knowledge. As a believer, who considers himself in the process of 'learning' assesses: 'With the opening of Albania, also the religion came here ... you accept and step by step you may arrive at some point, ... we are learning the religion at the moment, we are at the start of learning.' (Tošić 2015). The expansion of piety movements which embrace a new kind of Islamic knowledge demonstrates that believers seek new channels and sources of information - informal meetings, multiple authorities and alternative sources including open debates as much as official Islamic interpretations - to learn about Islam (Olson 2015; Mesarič 2015). As a pious woman from Bosnia puts it:

If you want to learn about Islam at the mosque, the hodža (imam) will only speak to you during Ramadan, and if he happens to be ill, not even then. And on top of that, he repeats the same thing every year. ...I want more. (Mesarič 2015)

It is usually through the non-official channels of learning that believers discover faith beyond national precepts and traditional dogma of organized religion.

Tradition - a collection of local beliefs and customs that is shared across generations - however, 
remains a crucial point of reference through which believers make sense of incoming new sources of knowledge. As a study on marriage preferences among Macedonian speaking Muslims shows that they do consider outsiders as 'different from our Muslims, having different culture, customs and tradition.' (Zadrożna 2015). Accordingly, culture and what it connotes for family models and gender roles determines Muslims' choices such as marriage and love relations, even if they venture into illicit romances when living abroad. Pilgrimage and the cults of saints among the Muslim Roma similarly show the stickiness of tradition, which combines a layer of pre-existing Islamic rites, Sufi practices and popular beliefs (Trofimova 2015). Such practices survive and acquire a life of their own, even if they stand in stark contrast to the teachings of the Islamic establishment, which tries to free the local habitus from 'elements of ignorance and innovation.' (Ibid.)

Whereas informal faith communities diffract from traditional knowledge supplied by official organizations, they also screen and select among religious alternatives on offer. Not all ideas, activities and networks that permeated the Balkans during the post-Communist openings are similarly welcomed by local believers. To paraphrase the concerns of a Muslim believer from Bosnia:

In the war and after the war, a lot of people started to go to mosque or to church here. The "need for God" was on such a high level. In [those]... extreme conditions and dangerous circumstances, after a sort of atheistic communism, it is very normal to try to find an "exit" in religion/s. ... I was just afraid that my good friend... [would accept] an extreme... interpretation of Islam...' (Funk 2015). 
Resistance against radical movements and doctrines is the main thread of centralized religious hierarchies that safeguard traditional knowledge and protect their monopoly of interpretation. Yet, Salafi and other radical forms of Islam have also achieved limited gains amongst lay believers and groups that resort to ideas different from those packaged as traditional (Bougarel 2005). Informal faith communities have seemingly resorted to different aspects of 'tradition' the body of institutional solutions, arguments and practices inherited from the past - to juxtapose radical projects and re-cast Islam in line with the new democratic and European aspirations of their post-Communist polities (Elbasani 2015).

The post-Communist reconfiguration of Islamic actors and ideas has allowed for the development of more personalized and individual attitudes towards religion. In the context of the market of religiosity, the Islamic 'community' appears scattered, heterogeneous and not particularly concerned with unifying itself or even with being represented (Roy 2007, 68-9). Forms of religiosity involve autonomous 'pick-and-choose' discoveries of faith while Muslims keep learning from alternative sources and channels of information. All the while, Islam is no longer only the bearer of ethno-national alternatives and political prescriptions, but also the symptom of religious spaces that cannot be confined within a particular nation, state territory, or ethnicity.

\section{Conclusions}


This article investigated the multitude of actors that speak for Islam and their respective alternatives in the context of the contemporary disruptions of organized religious 'field', across the post-Communist Balkans. In particular, the article explored the bifurcation between the macro-political debates that consider religion as a source of national identity and believers' own discoveries, choices and expressions of faith. Muslims' pursuit of faith amidst alternative channels and sources of knowledge has contributed to recasting the relationship between nation, state and faith beyond national dogmas or official suppliers of knowledge. The result is the creation of informal communities that seek to define a religious attitude towards the world and strive to observe their faith.

This gap between state-organized religion featuring its own actors, ideas and mechanisms of diffusion on the one hand; and informal faith communities embracing alternative ideas, sources and networks on the other, represents the emergence of different visions of Islam. State authorities and religious hierarchies responsible for 'guarding' the nation emphasize the differences between 'good' traditional or cultural Islam and 'bad', over-pronounced imports. They perform checks of 'authentic' and 'genuine' traditions in the interest of preserving nations' criteria for inclusion and exclusion. In this perspective, the revival of Islam is read through 'our' tradition and is seen as reinforcing identity, even civilizational, conflicts between the national 'us' and incoming 'others'. Faith communities, for their part, congregate into autonomous groups that strive to practice Islam as faith, and not as culture, tradition, or ethnic categorization. They avail of the various opportunities at offer and benefit from new channels of information as well as familiar sources and practices, in taking ownership of their local 'ways' of being Muslim. Hence, Islam, as framed at the top-down political level, remains an important marker of 
collective identity, but the experience of religiosity has increasingly become a more individual attitude, detached from organized official structures and prescriptions. If there is a common finding amongst the alternative pathways to God explained here, it is that believers' respective pursuits of faith are increasingly personalized, mobile, weakly institutionalized, and collective as a choice.

The 'de-nationalization' and 'de-ethnization' of Islam does not necessarily entail 'deculturation,' but rather the recasting of the connection between religious, cultural and political markers; it opens up the 'religious sphere', by making faith a choice, a set of beliefs distinct from the traditional body of knowledge and schemes of belonging. Religious 'revival,' moreover, does not work in favour of any kind of pan-Islamism or even uniform religious revival. It simply contributes to making religion more autonomous politically, institutionally and ideologically. Overall, these findings shed light to broader and timely theoretical questions on the various actors that speak for Islam, the role of foreign influences, the dynamic interaction between nation, state and faith and the evolving traits of religiosity in the larger post-Communist context.

What is interesting, and requiring further research, is to explore why and how both the political guardians of the nations and autonomous faith communities resort to traditional sources and embrace local-specific Islam(s). State elites, intellectuals and believers across the region have long sought answers concerning the most appropriate forms of organization, articulation and public expression of Islam in the context of modern and secular European 'civilization'. However, future research needs to inquire into how particular legacies, arguments and practices 
inform believers' screening of the alternatives on offer during the post-Communist open market of religiosity.

\section{Bibliography}

Bougarel, X. 2005. The Role of Balkan Muslims in Building European Islam. EPC Issue paper no 43.

Clayer, N. 2008. Behind the Veil. The Reform of Islam in Inter-War Albania or the Search for a 'Modern' and 'European' Islam. In Islam in Inter-War Europe eds. N. Clayer, and E. Germaine, E. New York: Columbia University Press.

Clayer, N. and E. Germain. 2008. Islam in Inter-war Europe. New York: Columbia University Press.

Creed, G. 2011. Masquerade and Post-Socialism: Ritual and Culture Dispossession in Bulgaria. Bloomington: Indiana University Press.

Duijzings, G. 2000. Religion and the Politics of Identity in Kosovo. London: Hurst and Company.

Elbasani, A. 2015. Islam and Democracy at the Fringes of Europe: The Role of Useful Historical Legacies. Politics and Religion, Online First: http://dx.doi.org/10.1017/S1755048315000012.

Elbasani, A. ed. 2013. European Integration and Transformation in the Western Balkans: Europeanization or Business as Usual? Abingdon: Routledge. 
Elbasani, A. and B. Saatcioglu, B. 2014. Muslims' Support for European Integration: The Role of Organizational Capacities. Democratization 21 no 3: 458-480.

Endresen, C. 2015. Faith, Fatherland, or Both? Accommodationist and Neo-Fundamentalist Islamic Discourses in Albania. In The Revival of Islam in the Balkans: From Identity to Religiosity, ed. A. Elbasani and O. Roy. London: Palgrave, forthcoming.

Funk, J. 2015. Public Expressions of Bosnian Muslim Religiosity and Lived Faith: The Cases of Friday Prayer and the Hijab. In The Revival of Islam in the Balkans: From Identity to Religiosity, ed. A. Elbasani and O. Roy. London: Palgrave, forthcoming.

Gellner, E. (1983) Nations and Nationalisms (Oxford: Blackwell).

Ghodsee, K. 2010. Muslim Lives in Eastern Europe. Gender, Ethnicity and Transformation of Islam in Post-Socialist Bulgaria. Princeton: Princeton University Press.

Hann, C. and Pelkmans, M. 2009. Realigning Religion and Power in Central Asia: Islam, Nation State, and (Post) Socialism. Europe Asia Studies 61, no. 9: 1517-41.

Henig, D and K. Bielenin-Lenczowska. 2013. Recasting Anthropological Perspectives on Vernacular Islam in Southeast Europe. Anthropological Journal of European Cultures 22, no. 2: 1-11.

Karcic, H. 2010. Globalization and Islam in Bosnia: Foreign Influences and their Effects. Totalitarian Movements and Political Religions 11, no. 2: 151-66.

Karic, E. 2002. Is 'Euro- Islam' a Myth, Challenge or a Real Opportunity for Muslims in Europe? Journal of Muslim Minority Affairs 22, no. 2: 435-42.

Katsikas, S. 2009. European Modernity and Islamic Reformism among Muslims of the Balkans in the Late-Ottoman and Post-Ottoman Period (1830s-1945). Journal of Muslim Minority Affairs 29, no. 4: 537-543. 
Mehmeti, J. 2015. Faith and Politics in Kosovo: The Status of Religious Communities in a Secular Country. In The Revival of Islam in the Balkans: From Identity to Religiosity, ed. A. Elbasani and O. Roy. London: Palgrave, forthcoming.

Mesarič, A. 2015. Muslim Women's Dress Practices in Bosnia-Herzegovina: Localising Islam through Everyday Lived Practice. In The Revival of Islam in the Balkans: From Identity to Religiosity, ed. A. Elbasani and O. Roy. London: Palgrave, forthcoming.

Oktem, K. 2011. Between Emigration, De-Islamization and the Nation-State: Muslim Communities in the Balkans Today. Southeast European and Black Sea Studies 11, no. 2: $155-71$.

Olson, L. 2015. The Multiple Voices of Bulgaria's Unofficial Islamic Leaders. In The Revival of Islam in the Balkans: From Identity to Religiosity, ed. A. Elbasani and O. Roy. London: Palgrave, forthcoming.

Poulton, H. and S Taji-Farouki. Ed. 1997. Muslim Identity and the Balkan State. London: Hurst.

Roy, O. 2007. Secularism Confronts Islam. New York: Columbia University Press.

Sadriu, B. 2015. Rhetorical Strategies of Kosovo's Imams in the Fight for 'Women's Rights'. In The Revival of Islam in the Balkans: From Identity to Religiosity, ed. A. Elbasani and O. Roy. London: Palgrave, forthcoming.

Sakellariou, A. 2015. Anti-Islamic Public Discourse in Contemporary Greece: The Reproduction of Religious Panic'. In The Revival of Islam in the Balkans: From Identity to Religiosity, ed. A. Elbasani and O. Roy. London: Palgrave, forthcoming.

Sulstarova, E. 2015. Islam and Orientalism in Contemporary Albania. In The Revival of Islam in the Balkans: From Identity to Religiosity, ed. A. Elbasani and O. Roy. London: Palgrave, forthcoming. 
Tošić, J. 2015. The Loudspeaker of Faith in the 'Calm' City: Islam and Urban Diversity in the Contemporary Balkans. In The Revival of Islam in the Balkans: From Identity to Religiosity, ed. A. Elbasani and O. Roy. London: Palgrave, forthcoming.

Trofimova, K. 2015. 'Holiness' Constructed: Anonymous Saints in the Popular Traditions of Muslim Roma Communities in the Balkans. In The Revival of Islam in the Balkans: From Identity to Religiosity, ed. A. Elbasani and O. Roy. London: Palgrave, forthcoming.

University of Oslo. Survey Conducted in the Framework of the Project: Strategies of Symbolic Nation-Building in West Balkan States -Intents and Results. http://www.hf.uio.no/ilos/english/research/projects/nation-w-balkan// (accessed 15 June, 2014).

Verdery, K. 1994. Ethnicity, Nationalism, and State-Making. In The anthropology of Ethnicity: Beyond 'Ethnic Groups and Boundaries'. Ed. H. Vermeulen and C. Govers, 33-58. Amsterdam: het Spinhuis.

Zadrożna, A. 2015. Love and Boundaries: Inter-Faith and Inter-Ethnic Relationships Among Macedonian-Speaking Muslims. In The Revival of Islam in the Balkans: From Identity to Religiosity, ed. A. Elbasani and O. Roy. London: Palgrave, forthcoming. 